\title{
ラット免疫グロブリンの分離と子宮液中における免疫 グロブリンの同定について
}

\author{
長谷川喜久* - 菅 原七 郎・竹内三郎 \\ (東北大学農学部 家畜繁殖学教室)
}

発情前期のラットの子宮分泌液中に, 血清蛋白質であ る albumin と globulin および子宮液に特異的である と考えられる多くの蛋白質が含まれていることを著者ら はすでに明らかにした ${ }^{1 \sim 3)}$ 。また, 発情前期から発情期 にかけて增加する子宮液の蛋白質の多くは， $\gamma$-globulin であることを明らかにした1)。しかしながら，ラット子 宮液中の immunoglobulin の種類については, まだ殆 ど知られていない。従って，これらに関する知見を得る ことは, 生殖免疫学的な観点から非常に重要であるとい われている4 7)。そこで, 本研究においてまずラットの immunoglobulin 特に IgG と IgA ${ }^{8 \sim 11)}$ の分離を試み, それらの性質を検討した。さらに, 生殖免疫学的観点か ら, 子宮液中の immunoglobulin の同定を行った。

\section{材料および方法}

\section{1）血清，子宮液および初乳}

血清および子宮液の採取は前報の方法により行っ た1)。初乳は分婏後 2 日から 3 日目の新生览のラットの

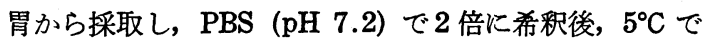
12,000 r. p. m. 1 時間遠心分離を行って乳清を分離し, 以後の実験に用いた。

硫安飽和溶液による塩析 ${ }^{12)}$, disc 電気泳動法, amido black による染色などは常法により行った ${ }^{11}$ 。

2) Column chromatography

Gel は sephadex-G200 と sepharose-6B を用いた。 いずれも PBS 溶液中で膨潤させた後に, 長さ $100 \mathrm{~cm}$, 直径 $2 \mathrm{~cm}$ の column に充填した。緩衝液の流速は 1 $\mathrm{m} l / \mathrm{cm}^{2} / \mathrm{hr}$ で行った。流出液は $3 \mathrm{ml}$ ずつ分取し, 分光

*現所属: 群馬大学医学部産婦人科学教室

Isolation of rat immunoglobulins and determination of immunogiobulins in rat uterine fluid.

Hasegawa, Yoshihisa*, Shichiro Sugawara \& Saburo TAKEUCHI (Laboratory of Animal Reproduction, Tohoku University, Sendai; *Present address: Department of Obstetrics and Gynecology, School of Medicine, Gunma University, Maebashi 371)

Jap. J. Animal Reprod. 22 (4), 1977.
光度計により波長 $280 \mathrm{~m} \mu$ を用いその吸光度を測定し た。イオン交換 chromatography は, 長さ $50 \mathrm{~cm}$, 直 径 $3 \mathrm{~cm}$ の column に充填した DEAE cellulose を用 いて行った。

3) SDS polyacrylamide gel 電気泳動法

WEBER と OSBORN ${ }^{13)}$ および DUNKER と BUECKERT ${ }^{14)}$ の原法および林と大場の改良法福により行った。acrylamide の濃度が 5\% の gel を用い, tracking 色素 は, $0.1 \%$ の coomasie brilliant blue R250 溶液を用 いた。蛋白質の SDS 化は $50^{\circ} \mathrm{C} に 2$ 時間置いて行った。 2-mercaptoethanol (2-ME) 処理をする場合は, 2-ME の終末濃度が $4 \%$ になるように試料に加えて SDS 化 を行った。 acrylamide, bisacrylamide は,それぞれ chloroform と acetone で精製してから用いた。染色は 電気泳動後に coomasie brilliant blue G250 によって 行った ${ }^{16)}$ 。

蛋白質分画の易動度を測定した後, 標準蛋白質として は thyroglobulin (MW: $65 \times 10^{4}$ ), ferritin (MW: 54 $\times 10^{4}$ ), bovine $\gamma$-globulin (MW: $17.5 \times 10^{4}$ ), bovine serum albumin (MW: $\left.6.7 \times 10^{4}\right), \quad \beta$-lactoglobulin (MW: $\left.3.6 \times 10^{4}\right)$ および chymotrypsinogen A (MW: $\left.2.5 \times 10^{4}\right)$ などを用い各分画の蛋白質の分子量を概算し た。

4）蔗桾密度勾配遠心分離法

$0.01 \mathrm{M}$ のリン酸緩衝液を用いて $5 \%$ から $20 \%$ の蔗 糖密度勾配液 $4 \mathrm{ml}$ 亿試料を $0.2 \mathrm{ml}$ 載せ, 日立の $R P$ 400 の roter を用い, 35,000 r. p. m. で 8 時間遠心分離 を続けた。分子量の標準蛋白質としては, urease (MW: $\left.48.5 \times 10^{4}\right)$ と catarase (MW: $\left.22 \times 10^{4}\right)$ を用いた。

5) Ouchterlony 法拈よび免疫電気泳動

前報3) と同様に行った。

6) $\operatorname{IgG}$ と IgA の分離

IgG の分離は, 硫安の $40 \%$ 飽和により血清から得た globulin DEAE cellulose column chromatography により行った ${ }^{17)}$ 。流出液は， $0.01 \mathrm{M} ： \mathrm{pH} 7.5 \cdot 0.02 \mathrm{M}$ $\mathrm{pH} 6.2 \cdot 0.05 \mathrm{M}: \mathrm{pH} 5.3$ のリン酸緩衝液を順次用い, 
最後に， $0.5 \mathrm{M}$ の $\mathrm{NaCl}$ を含んだ $0.05 \mathrm{M}$ のリン酸緩 衝液で溶出した。

血清からの IgA の分離は硫安 $33 \%$ 飽和により得た r-globulin を sepharose-6B により分画した。

初乳中の $\operatorname{IgA}$ は前述の乳清を酢酸により $\mathrm{pH} 4.6$ に 調整し沈澱物を除さ，さらに硫安 $50 \%$ 飽和によって albumin を除いた後に sephadex-G200, sepharose-6B 拉よび DEAE cellulose column chromatography に よって分画した。

\section{実験結果}

\section{Immunoglobulin の分離}

1) IgG: DEAE cellulose column chromatography の結果は Fig. 1 に示すように 4 分画に分かれたが，図 示したように 5 分画に分けて各分画の蛋白質成分を免疫 電気泳動によって分析した。その結果，第 I 分画は最も 陰極側に 2 本の沈降線を示していたので $\mathrm{IgG}_{2}$ 分画と推 定する。第II分画は，第 I 分画の蛋白よりやや陽極側保 1 本の沈降線を示し $\mathrm{IgG}_{1}$ 分画と推定される。第正分画 および第I分画には， IgG I $_{1}$ と他の globulin が混在し ていた。第V分画には多種の globulin が含まれており， IgA および IgM はこの分画に混入していると考兄ら れる。

2) IgA: sepharose-6B column chromatography によって得られた結果は Fig. 2a に示し，各 peak の 免疫電気泳動像は Fig. $2 b$ に示した。第 2 峰以陽極側 の蛋白質であり，第 3 峰は陰極に移動する蛋白質であっ た。しかし第 1 峰は DAUGHADAY の蛋白質の測定法 ${ }^{11}$ に よっても蛋白質は全く検出でさなかった。

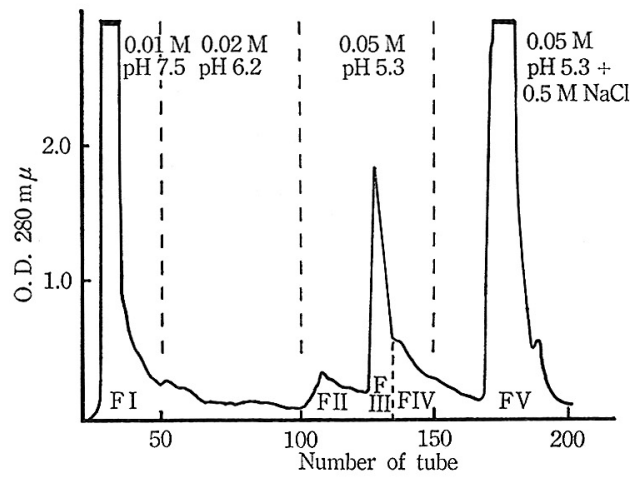

Fig. 1. Fractionation of rat serum $r$-globulins by DEAE-cellulose chromatograthy with stepwise addition of phosphate buffers.

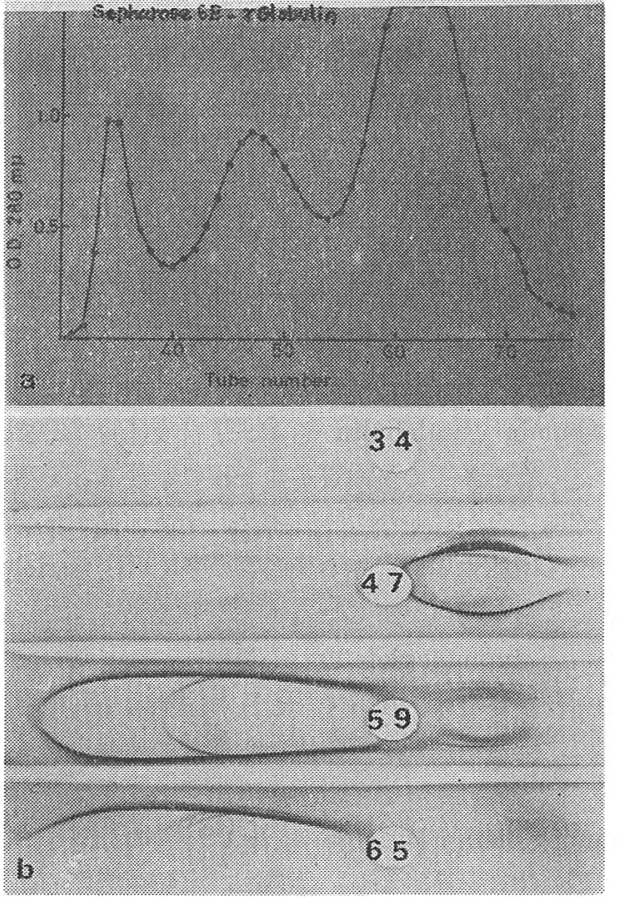

Fig. 2a. Fractionation of rat serum $r$-globulins by sepharose- $6 \mathrm{~B}$ column chromatography.

Fig. 2b. Each peak was analyzed for immunoglobulin by immunoelectrophoresis.

次に初乳から IgA の分離を行った。 sephadex-G200 column chromatography によって得た第 1 峰を sepharose-6B column chromatography 分画像を得た。免疫電気泳動の結果から最初の peak は IgM, 次の peak は IgA 分画であることがわかった。

血清㧍よび初乳より得た IgA は disc 電気泳動では 原点よりわずかに移動するのみであった。免疫電気泳動 像では，それぞれのIgA は原点よりやや陽極側位置 していたが，血清 IgAは 乳清 IgA よりもわずかながら 陽極側に移動した。血清と乳清の IgA き Ouchterlony 法で分析した結果, これらの IgA は融合し, 免疫化学 的に等しいことがわかった (Fig. 3b)。

次にこれらの IgG 拉よび IgA の物理化学的性質に ついて検討した。SDS 電気泳動の結果は Fig. 4 亿示す

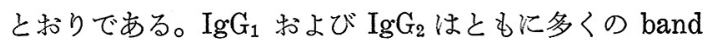
に分かれたが， bovine $\gamma$-globulin や aldorase に近い 位置に主な分画が認められた (Fig. $4 \mathrm{~A} ， \mathrm{~B}$ )。また 2ME 処理により，この蛋白質分画は分子量の小さい $3 つ$ の band に分か礼た。血清と乳清の IgA は, 原点近く の thyroglobulin と ferritin の間の位置に band が 


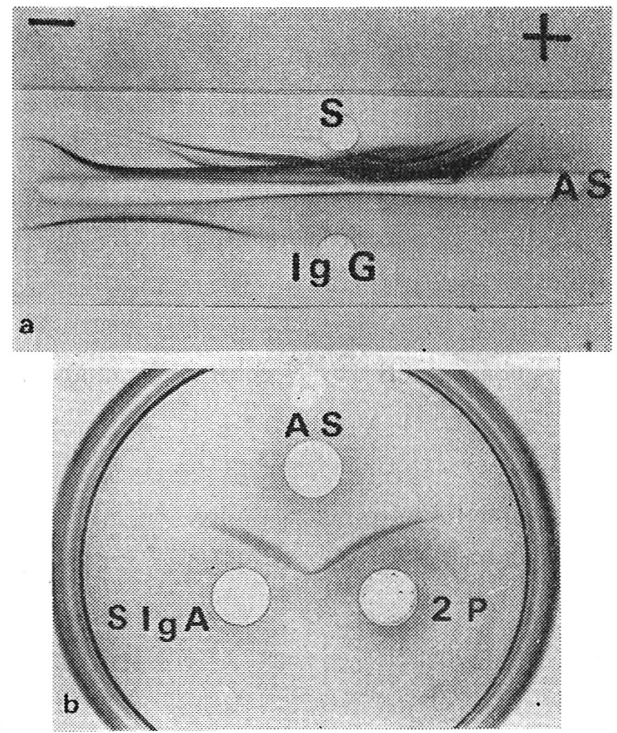

Fig. 3a. Immunoelectrophoretical analysis of serum protein, and IgG. Uper well contain normal rat serum (S), and lower well IgG.

Fig. 3b. Ouchterlony test of rat $\operatorname{Ig} A$. Uper well contain anti-rat serum antiserum, lower left contain secretary IgA (SIgA) obtained from colostrum and lower right contain secouns peak in Fig. 2 a.

現れた。また，2-ME 処理することにより3つあるいは それ以上の蛋白質に分割された。

血清 IgA について, さらに蔗糖密度勾配超遠心法に よって検討したが，Fig. 5 に示すと特り，血清 IgA は 標準蛋白質の urease より高分子であることがわかっ た。

3）ラットの IgG と IgA の共通性について：Ouchterlony 法によって分析したところ，IgG と IgA の 間に交差反応が見られた。さらに，抗 IgA 家免血清を IgG で吸収した後にも，その抗体とラットの IgA との 間に反応がみられた。

\section{2. 子宮液中の immunoglobulin}

発情前期の子宮液中に $\gamma$-globulin に相当する蛋白質 が多量含有されていることは実験の結果明らかになった $か^{1,3)}$ ，さらに免疫化学的な検討を加えた。抗子宮液抗 体 (AUF) と血清および血清で吸収した抗子宮液抗体 $(\mathrm{AUF}+\mathrm{S})$ に子宮液を反応させると，globulin 領域に 位置する子宮液に多量に含まれている蛋白質は，AUF に血清あるいは子宮液を反応させると沈降線を形成し た。しかし, 吸収後の抗体に子宮液を反応させても沈降

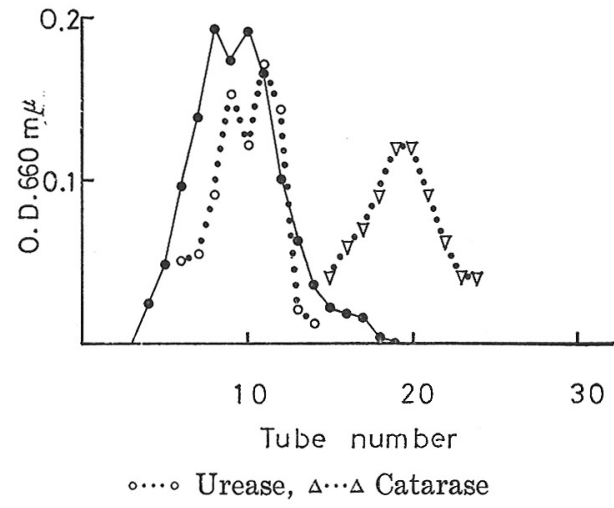

Fig. 5. Density gradient ultracentrifugation of rat serum IgA compared to marker proteins. Sedimentation is from right to left.

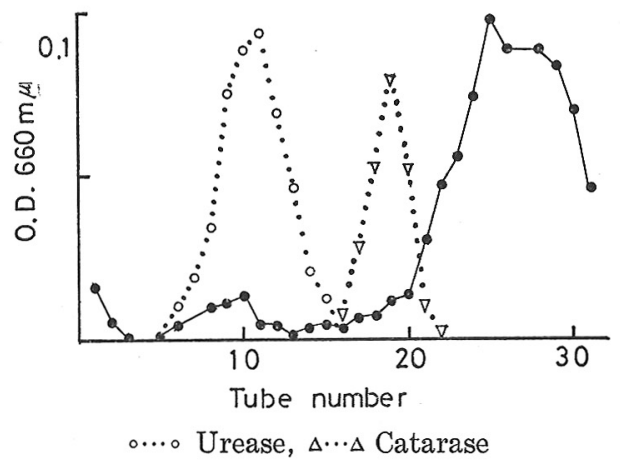

Fig. 7. Density gradient ultracentrifugation of rat uterine fluid at 22:00 of proestrus compared to marker proteins.

反応は認められなかった。次に血清と乳清から得た IgG， IgA，IgM と AUF のそれぞれの閒の反応では，IgG とは痕跡程度の沈降線が認められるにすざず，子宮液中 に IgG の少ないことが示された。IgM に対しては，不 明瞭な沈降線が認められた。IgA と AUF と反応では 極めて鋭敏な沈降線を形成し，その沈降線の位置は，血 清とAUF の反応で観察された沈降線の位置とほぼ一 致した。この沈降線は, 血清および初乳から分離した $\operatorname{IgA}$ が示した沈降線よりもさらに陰極側にあり， $\operatorname{IgG}_{1}$ の位置にまで伸びていた。 $\mathrm{IgG}_{1}$ と AUF との間には， 極めて微弱な沈降線の形成しか認められなかった。

蔗糖密度勾配法により子宮液中の蛋白質の分子量を測 定し，前述の IgA の分析の結果と比較検討した（Fig. 7)。その結果, 子宮液の蛋白質は, catarase より分子 量の小さいものが殆どであり, 大きいものは少なかっ 
た。しかしなが, 前述の IgA の沈降位置, さらに高分 子分画の位置に peak を認めた。

\section{考察}

人やマウスの immunoglobulin については，その物 理化学的, 免疫化学的性質や allotype の遗伝学的性質 について非常に多くの研究が見られる。しかしラットの immunoglobulin に関する研究は比較的少ないようであ る。初め ARNASON ら ${ }^{18)}$ によってラットの immunoglobulin は IgG と IgX に分類され, その後, IgG に は IgGa と IgGb の subclass が発見され，IgX は， その易動度が人の IgA に類似していることから IgA と 考えられた。しかし，蛋白質の物理化学的性質は IgA とは異なり， $\gamma_{1}, 7 \mathrm{~S} \gamma_{1}$, あるいは $\mathrm{IgG}_{1}$ と呼ばれている immunoglobulin に属するものの一種であった ${ }^{19)}$ 。しか し, ラットの $\operatorname{IgA}$ は最近になって, $\gamma$-globulin の免疫電 気泳動による沈降線について, 各々の immunoglobulin が同定されることにより， IgA の位置も示された ${ }^{20) 。 ~}$

一般に immunoglobulin の分離は種々の chromatography や電気泳動法などにより行われているが，本研 究に执いても，IgG の分離法は DEAE cellulose を用 いたイオン交換 column chromatography により, IgA の分離法は sephadex-G200 および sepharose-6B を 用い column chromatographyによって行った。IgGに 用いる緩衝夜は分離する subclass や動物の種などによ り種々のものが使用されている。著者らは，リン酸緩衝 液を用い，イオン交換 chromatographyにより IgGの 分離を行った ${ }^{17,21) 。 ~}$

すでにラットの外分泌物より IgA の分離は試みられ ているが，血清 IgA の分離はあまり行われていない。 sephadex-G200 を用いた column chromatography によって IgA を単離することができなかったので, sepharose-6B を用いた column chromatography に より, 塩析で得た $\gamma$-globulin からの $\operatorname{IgA}$ 分離を試み たところ，ほぼ単一の蛋白質を得ることができた。人血 清の IgA は monomer であり分子量は分泌型 $\operatorname{IgA} の$ 半分以下で, IgG のそれに近似しているとされている11。 本研究においてラットの IgG および IgA についての 物理化学的性質を検討した結果, IgG の分子量は約 16 万で，3つの subclass から構成されていると推定され た。血清㧊よび乳清から得た IgA の分子量は IgG の 約 3 倍であり, IgG 同様に 4 つの subclass の存在が示 唆された。さらに人とラットの immunoglobulin を比 較するために, 人の IgG と血清 IgA を SDS 電気泳
動により分析したところ，人の IgG の泳動像とラット の IgG の泳動像は類似していたが，ラットと人の血清 IgA の泳動像は異なり生物物理化学的に性質の異なる ことが明らかになった。

従来, ラットの分泌液中の IgA の分離は主に初乳を用

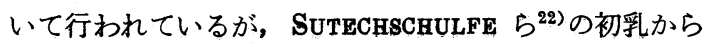
の IgA の分離法を試みたが，未だかなりの混入物があ った。そこで, 本実験では, 酢酸および硫安による処理 および sepharose-6B による column chromatography を行らことにより IgA を単離することができた。 他の動物17の IgA の分離に用いられている DEAE cellulose column chromatography を応用したラット の初乳 IgA の分離法では, 本実験においては他の報 告 ${ }^{17,22)}$ に示されたような良い結果は得られなかった。

免疫生殖学の研究により, 雌の生殖器管に抗精子抗体 が産生されると，それが不妊の原因となる可能性のある ことが報告されている4,b)。それらの抗体の産生される 機序については,すでに多くの研究がみられるとはい光, 末だ不明の点が少なくない。特に，それらの過程におけ る抗原の感作之, その後の生殖器道分泌液への抗体の 移行について明らかにするため, 種々の動物について immunoglobulin の検索および同定が試みられている。 しかしながら，ラットの子宮液中の immunoglobulin に関する報告はみられない。本研究に批いて, ラット血 清中の immunoglobulin の性質を検索するととももに, 子宮液中の immunoglobulin についても検討した。 IgG は, 発情前期から発情期の子宮液中には殆ど認め られなかた。従って，交尾により子宮内に入った精子は IgG 抗体に曝される危険性は殆どないと考えられる。 なお，卵管における感作については不明であるが，少な くとも妊娠初期の子宮液中の immunoglobulin の組成 は血清のそれに類似しているところから ${ }^{23)}$, 受精卵の成 長または着床時期に卵が IgG 抗体による阻害を受ける 可能性がある。

IgA については，未だ不明の点があるが，子宫液中 には $\gamma$-globulin が多く存在し, 分子量から推定すれば IgG like であるが, 免疫学的には抗 IgG 抗体とは沈降 線を形成せず，むしろ抗 $\mathrm{IgA}$ 抗体と交差した。兔疫電 気泳動における沈降線はより原点に近いところ（既知の $\operatorname{IgA}$ に近い位置) に認められるので，子宮液に多い globulin はおそちらく IgA であろうと考学られる。その 蛋白質の物理化学的性質は, 血清および乳清から分離し た IgA とは異なるもので，分子量も小さいものと思わ れる。 
1977 年 2 月

これまでの研究19)によって, ラットの血清 IgA は高 分子型と低分子型の 2 種類があることが示唆されている ことなどを考え合わせると，ラット子宮液中に特に多い 血清蛋白質は, 血清中の低分子の $\operatorname{IgA}$ が透過して子宮 液中に認められるためであろらと推定される。

このように, 著者らの研究によってラットの発情期の 子宮液中の蛋白質組成の特異性が明らかにされたが, 血清と子宮液中の immunoglobulin の組成の違いは子 宮組織により制御されているものと思われる。

\section{要 約}

本報では，ラットの immunoglobulin の分離同定お よびその物理化学的性質をしらべると共に, 子宮液中の immunoglobulin の存在様式の特異性について 検討し た。

IgG と IgA は血清および初乳乳清から, 塩析, gel 沪過およびイオン交換 column chromatography によ って分離された。それらの物理化学的性質の検討を disc および SDS gel 電気泳動, 免疫電気泳動および蔗糖密 度勾配遠心分離により行ったところ， IgG と IgA の分 子量, それらの subclass と免疫化学的性質が明らかに された。

子宮液中の immunoglobulin について, 免疫化学的 方法により同定したところ, IgG が著しく少なく, IgA と免疫化学的に共通であり, IgA より分子量の小さい immunoglobulin が認められた。

(1976. 7. 15 受付)

\section{文献}

1) 長谷川 (喜) - 菅原 (七) - 竹内 (三)： 本誌， 19, 26, 1973.

2) 長谷川 (喜) - 菅原 (七) - 竹内 (三)： 本誌， 19, $73,1973$.

3) Hasegawa, Y., S. Sugawara \& S. Takeuchi: Tohoku J. Agr. Res. 25, 67, 1974.

4) 礒島 (晋): 妊孕現象に関する免疫学的研究 第 23 回日本産科婦人科学会宿題報告, 東京, 1971.

\section{家畜繁殖誌 22 巻 4 号}

5) Behrman, S.J.: The Mammalian Oviduct ed. B.J. Blandau \& E.S.E. Hafez. The University of Chicago Press Chicago, London 1971.

6) EDWARDS, R.G.: Immunology and Reproduction ed. R. G. EDwARDS, International Planned Parenthood Federation London 1969.

7) Behrman, S. J., M. E. Lieberman, N. Uchida \& R. Ansbacher: Pathways to Conception ed. A. I. Sherman, C. C. Thomas Publisher Springfield, Illinois 1971.

8) Tomasi, T. B. \& J. Bienenstock: Advances in Immunology Vol. 9 ed. F.J. Dixon and H. G. Kunkel, Academic Press Now York, London 1968.

9) Beer, A.E. \& R. E. Billingham: Advances in Immunology Vol. 14 ed. F. J. Dixson \& H. G. Kunkel, Academic Press New York, London 1971.

10）小林 (邦)：生物物理化学, 18, 35, 1974.

11) 小林 (次): 蛋白核酸酵素, 18, 828, 1974 .

12) 松岡 (雄): 免疫学・アレルギー学実験法, 進藤 宙二監修, 文光堂, 東京, 1971.

13) Weber, K. \& M. Osbon: J. Biol. Chem., 244, 4406, 1969.

14) Dunker, A. K. \& R. R. Rueckert: J. Biol. Chem., 244, 5074, 1969.

15）林 (健) - 大場 (義)：蛋白質核酸酵素, 17, 304, 1972.

16) Diezel, W., G. Kopperschlager \& E. Hofman: Analyt. Biochem., 48, 617, 1972.

17）臼井(美) - 成内 (秀) - 松橋 (直): 免疫化学, 中 山書店, 東京, 1973.

18) Arnason, B.G., C. de Vaux St. Cyr \& P. Grabar: Nature, 199, 1199, 1963.

19) BaziN, H., A. Beckers \& P. OUerinJeAN: Eur. J. Immunol., 4, 44, 1974.

20) Bistany, T.S. \& T.B. ToMASI: Immunochem., 7, 453, 1970.

21) JoNES, V.E.: Immunology, 16, 589, 1969.

22) Stechschulte, D.J. \& K. F. Austen: $J$. Immunol., 104, 1052, 1970.

23）長谷川 (喜) - 菅原 (七) - 竹内 (三)：本誌, 22, 109, 1976.

\section{Summary}

Present study was designed to isolate immunoglobulins from serum and colostrum whey, and determine immunoglobulins in uterine fluid of proestrous rat.

Results obtained were as follows:

1. Subclass of IgG and IgA in serum and colostrum whey were obtained by DEAE cellulose, sephadex-G 200 and sepharose-6B column chromatography (Figs. 1 3).

2. Physicochemical analysis of immunoglobulins were performed by SDS acrylamide gel electro- 
phoresis and density gradient ultracentrifugation methods (Figs. 4, 5). Molecular weight of isolated IgG and IgA was about $16 \times 10^{4}$ and $50 \times 10^{4}$, respectively.

3. Immunoglobulins in uterine fluid were determined by immunoelectrophoresis. Although high molecular IgA in uterine fluid determined by physicochemical analysis was very small amount, uterine fluid contained high level of the protein component reacted to serum $\operatorname{IgA}$, of which molecular weight is smaller than $20 \times 10^{4}$.

Immunoglobulin $\mathrm{G}$ was not appeared in the rat uterine fluid at 22:00 of proestrus.

\section{Explanation of Figures}

Fig. 4. SDS acrylamide gel electrophoresis of immunoglobulins.

(A) rat immunoglovulin $\mathrm{G}_{2 \mathrm{a}}$

(B) rat immunoglobulin $\mathrm{G}_{1}$

(C) human serum immunoglobulin $\mathrm{A}$

(D) rat serum immunoglobulin $\mathrm{A}$

(E) rat colostrum immnoglobulin $\mathrm{A}$

2ME, SDS gel electrophoretic pattern of protein treated with 2-melcaptethanol.

Fig. 6. Immunoelectrophoretic analysis of immunoglobulins and specific portein in uterine fluid at 22:00 of proestrus.

UF, uterine fluid $\quad$ AUF, anti-uterine fluid antiserum

$\mathrm{S}$, serum

$A U F+S$, AUF absorbed with serum protein 


\section{PLATE}
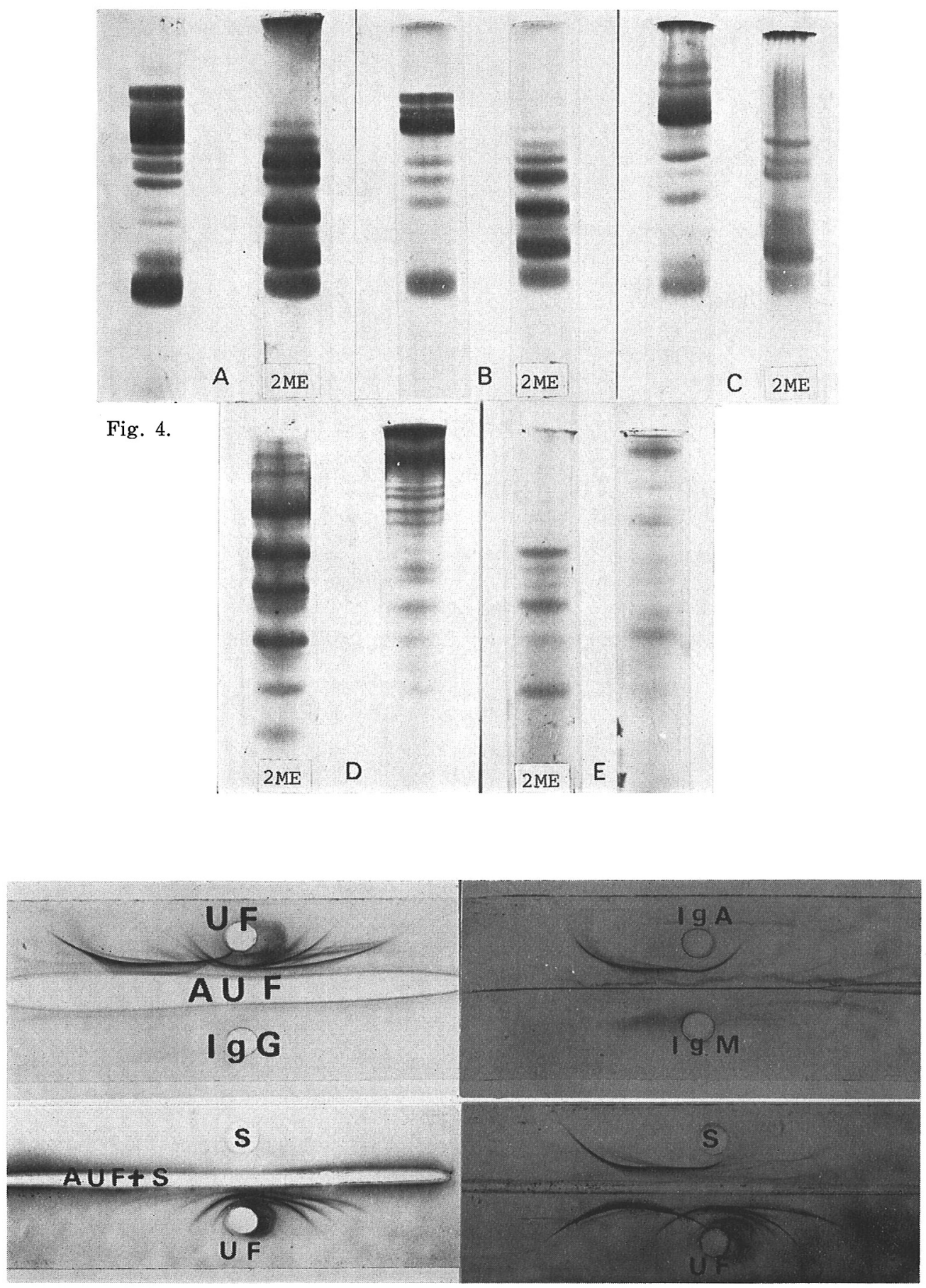

Fig. 6 . 